\title{
Stage Design at the Crossroads of Different Operational Cultures. Mapping the History of Scenography Education in Finland
}

The article maps the development of scenography education in Finland from the early 1970s to the 2000s. Unlike all other disciplines of theatre making, the study program has been located at the University of Industrial Arts, which highlights the double character of scenography as both a visual and a performative art. The hegemonic comprehension of the subject has oscillated between independent design and participation in a collective process. The key question that penetrates the curriculum throughout the decades is how to successfully

construct a solid, material space for a temporary, more or less unpredictable theatrical event. The scenographic methods that have been taught vary from the disciplined rational pre-planning and conceptual analysis of the 1970s, to the subjective individualism at the turn of the 1980s and 1990s, and finally to the interactive, self-regulating processes in the 2000s. The different approaches are largely connected to individual teachers, but they can be further contextualized by looking at the more general cultural tendencies in art, theatre and society; as well as to the material conditions, changing university policies and respective organizational reformations.

Keywords: scenography, stage design, University of Industrial Arts, Helsinki, theatre education, theatre professions.

BIOGRAPHY

Laura Gröndahl is a scenographer and theatre researcher, who is currently working on a research project on documentary theatre at Tampere University. Since taking her doctoral degree 2004 she has published several articles and acted regularly as a visiting lecturer at the Theatre Academy, and at the Universities of Lapland, Tampere and Helsinki, where she also holds the title of docent in theatre studies. She studied scenography in 1980-85, worked as a full-time practicing

designer 1983-2002, and was the professor of Stage Design in 2006-13 at the University of Industrial Arts, Helsinki (from 2010 at the Aalto University School of Arts, Design and Architecture). laurakgrondabl@gmail.com 


\section{Stage Design at the Crossroad of Different Operational Cultures. Mapping the History of Scenography Education in Finland}

\section{LAURA GRÖNDAHL}

I first undertook this investigation out of personal curiosity as a former student, practitioner and teacher in scenography. I wanted to know how the prevailing curriculum and study subjects had been constituted and developed into the shape in which I came to know them. They easily appear as something ahistorical, as if things would always have been the way they are, because the designing skills are learned by doing and knowledge is transmitted through oral interaction, which is not recorded anywhere. We may, thus, fail to see how they depend on wider social and cultural developments, and think of scenography as a fixed discipline, pre-existing its material conditions and temporal changes. I also soon realized the general relevance of the subject, since almost all Finnish stage designers are trained in the same place, and their education has a significant impact on the artistic and technical practices in Finnish theatre.

The article is based on interviews and preserved documents such as teachers' notebooks, minutes of their meetings, instructions for assignments and evaluation criteria, complemented by my own memories as a student and teacher. As I started to map this material, I had no idea how many different narratives and questions would arise. Within this limited space, I can only focus on the most intensive development from the 1970s to the early 2000s, leaving out many important aspects, such as the curricula of costume design, lighting design and production design for film and TV and the development of doctoral studies. Yet, some questions seemed to recur throughout the years: how space and vision function as communicative and performative means; how the creative processes take place; what are the basic components of scenography; and how to balance between technical skills and artistic creativity. The answers vary a lot. Two aspects have especially aroused my interest. Firstly, the individual teachers have understood the essence of scenography in very different ways and left their personal fingerprints on the study contents of their time. Secondly, the larger contexts of the institutional theatre system, university structures and pedagogic practices have had a significant impact on the curriculum. I will discuss these aspects in turn and try to show how individual aspirations and experiences intertwine with more general cultural, social and political development in the fields of both theatre and academic education.

\section{SCENOGRAPHY IN THE CONTEXT OF INDUSTRIAL ARTS}

As a cross-disciplinary discipline, scenography is a merger of different traditions and operational cultures, having one foot in theatre and the other in arts and crafts. The tension between the artistic principles of the performative and visual arts permeates the history of scenography education. Set design as an artistic occupation has existed in Finland since the $1910 \mathrm{~s},{ }^{1}$ when it was practiced by a handful of designers. They usually had some basic training in the visual arts, after which they learned the work as apprentices in theatres. For a short period in the 1950 s, a few scenography students were taken to 
the Finnish Theatre School, where they were trained at the workshops of the National Theatre. ${ }^{2}$ In the 1960s set design was taught as part of Decorative Painting and Exhibition Design studies in the Institute of Industrial Arts, ${ }^{3}$ which in 1973 turned into the University of Industrial Arts, Helsinki (from now on shortened as UIAH). In the same year, scenography was established as an independent degree programme in the Department of Visual Communication at UIAH. ${ }^{4}$

The Finnish theatre institution was intensively developed during the 1970s: new theatre houses were built; regional activity was promoted; local amateur theatres turned professional, and a lot of new vacancies for trained artists opened. The status of the scenographer was elevated from an artisan set-painter to an artistic designer requiring a university-level degree, but the right context for the education became a ticklish question. Many committees suggested that it should be moved to the Theatre Academy, ${ }^{5}$ which was granted its university-status in 1979. Scenographers were strongly opposed to this, arguing that the visual arts and artisan skills taught at UIAH were most vital for the profession, although a close collaboration with theatre education was necessary. ${ }^{6}$ Moreover, cinema and TV were growing fields for scenography and the training of camera arts was located at UIAH. Since the Theatre Academy worked in small provisional premises and could not house scenography students anyway, ${ }^{7}$ the study curriculum was placed at UIAH and it has stayed there ever since. ${ }^{8}$

In the 1970 s, UIAH was a small school where everybody knew each other and the boundaries between different departments were easily crossed. All students, regardless of their discipline, attended the same classes in their first year, which created for them a shared identity as visual designers. Kaj Franck, an industrial designer committed to Finnish functionalism, headed the school in 1960-66 and carried out a thorough reform of the curriculum. ${ }^{9}$ His pedagogical and philosophical legacy has been called the Bauhaus-tradition, ${ }^{10}$ although the connection between the famous design school in the Weimar Republic and UIAH has not been examined in detail. It is known that Franck had met former teachers of Bauhaus, including its main ideologist Walter Gropius. ${ }^{11} \mathrm{He}$ similarly tried to formulate universalizing principles for good design, derived from the common roots of all arts. He also stressed the importance of craftsmanship and work by hand, which, for him, was the only way of knowing the essence of different materials. ${ }^{12}$

The exact contents of the Bauhaus-tradition have also remained a bit fuzzy at UIAH. It is often referred to as a coherent style, ${ }^{13}$ although the Bauhaus-school actually contained several different, even contradictory orientations from neoromantic essentialism to politically oriented constructivism. The imprecision may be due to the practical tradition of learning by doing assigments, because the visual outcomes may look rather uniform regardless of their philosophical basis. The abstract geometric forms, emblematic of the Bauhaus, can be conceived of either as functionally optimal, minimalist shapes, or as incarnations of essentialist "ur-forms". Then again, perhaps the Bauhaus-assignments were so stimulating exactly because they could be connected to different background theories according to the students' individual interests. They clearly inspired many scenographers like Ralf Forström and Måns Hedström, ${ }^{14}$ who, in the 1960s and 1970s, introduced the functional aesthetic of the empty stage to Finnish theatre, thus opposing realistic conventions, as will be discussed later.

\section{PIONEERING TEACHERS IN SCENOGRAPHY}

The Bauhaus-tradition was taught mainly in shared art classes and the so-called Basic Course, and carried on by Franck's students and colleagues after he left the school in1966. Otherwise, the studies still largely resembled the previous apprenticeship system. Students worked under the guidance of old masters, whose pedagogy was not very systematic. ${ }^{15}$ Eeva Ijäs (studied 1972-76) and Maija Louhio (studied 1973-77) recall that there was no proper scenography tuition during their first years at UIAH. ${ }^{16}$ Rather, they assisted experienced designers or made their own productions and applied credits for them. Some of the preserved documents show how the students kept very precise diaries that consisted almost exclusively of practical occupations, ${ }^{17}$ although the working hours were arbitrarily cate- 
gorized under the titles: scenography, theatre work, professional knowledge and theatre technology.

The inadequacy of the vocational education caused several student revolts during the 1970s and 1980s and many teachers left the department. ${ }^{18}$ Some students, like Pekka Ojamaa and Eeva Ijäs, started to figure out by themselves what skills and knowledge were needed for their occupation and soon became part-time educators. Ijäs recalls being a well motivated teacher because she had studied during the problematic period: "I saw that the skills we had learned were not sufficient, and I got new ideas as to what should be taught." 19

A systematic development of the education began when Paul Suominen (born 1930) was hired as lecturer in 1974 and remained in charge of the education for almost twenty years. He learnt his occupation through an apprenticeship at the Helsinki Swedish Theatre in the late 1940s and moved to the Finnish National Opera at the beginning of the 1950 s. ${ }^{20}$ Being most skilled in set painting he represented the older generation and traditional craftsmanship, but was largely appreciated by both students and field-workers, perhaps also because of his successful activity in the trade union.

Suominen was convinced that the key to successful performances and production processes was rational thinking, which manifested itself in a detailed pre-planning of all stage elements and scene changes. ${ }^{21} \mathrm{He}$ developed a schematic model for designing and executing scenography, where preliminary sketches, floor plans, coloured sketches, final sketches, experiments with materials and scale models should be made in a given order, followed

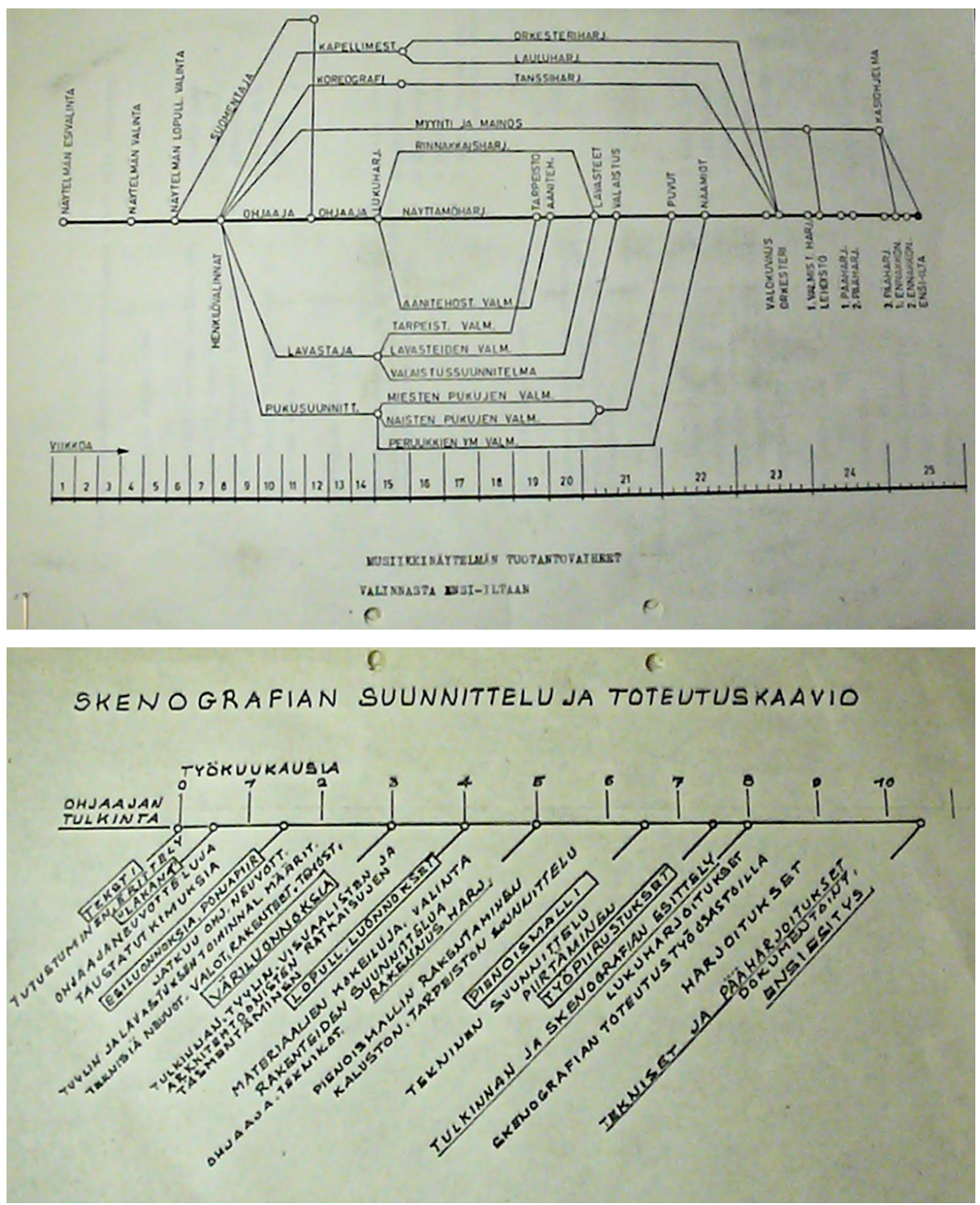

Fig. 1. Paul Suominen developed schematic models for linearly advancing production processes as an ideal working method. Above: the phases of the production process for a music play. Below: a scheme for the design and implementation of scenography lasting for 10 months. 
by construction work and rehearsals. ${ }^{22}$ It was clearly based on Suominen's career in the opera, where all pieces have to fall into their places with exact accuracy. However, it was rather his utopia of ideal work in perfect circumstances, which certainly did not equate with his own experiences: the ideal design process in his model would have taken ten months, while at the opera he had been used to producing the whole scenography within four weeks. ${ }^{23}$ The model did not match with the reality of the training productions at the Theatre Academy either. The reports made by the scenography students were packed with criticisms: the play-texts were received too late, the directors did not introduce their analysis in time, they neglected preparatory discussions with designers, ignored technical restrictions and hard facts. ${ }^{24}$

Giving classes mainly in perspective and technical drawing, Suominen was aware of his limitations concerning modern theatre. ${ }^{25} \mathrm{He}$ openmindedly hired visiting part-time teachers, including Måns Hedström (1943-2005), who was known for his minimalistic and playful sets in KOM-teatteri and became perhaps the most influential teacher in scenography at the turn of the 1970s and 1980s. Emphasizing his training as an interior architect, and considering himself as a successor of Franck and the Bauhaus-tradition, ${ }^{26}$ Hedström was the complete opposite of Suominen. The most typical assignment given by him was to make a minimalistic, small-scale spatial composition of a given abstract theme using only one material. ${ }^{27}$ In another exercise, he asked students to make relaxed and free brush strokes randomly on paper, frame the best outcomes and give them a title that makes them interesting. ${ }^{28} \mathrm{He}$ always wanted the students to develop their final works to a point of perfection, where there was nothing you could add or take away from it.

The obvious linkage between Hedström and the Bauhaus-tradition was the purification and compression of the spatio-visual expression into its elementary components and thinking through material. I have not found evidence that Hedström

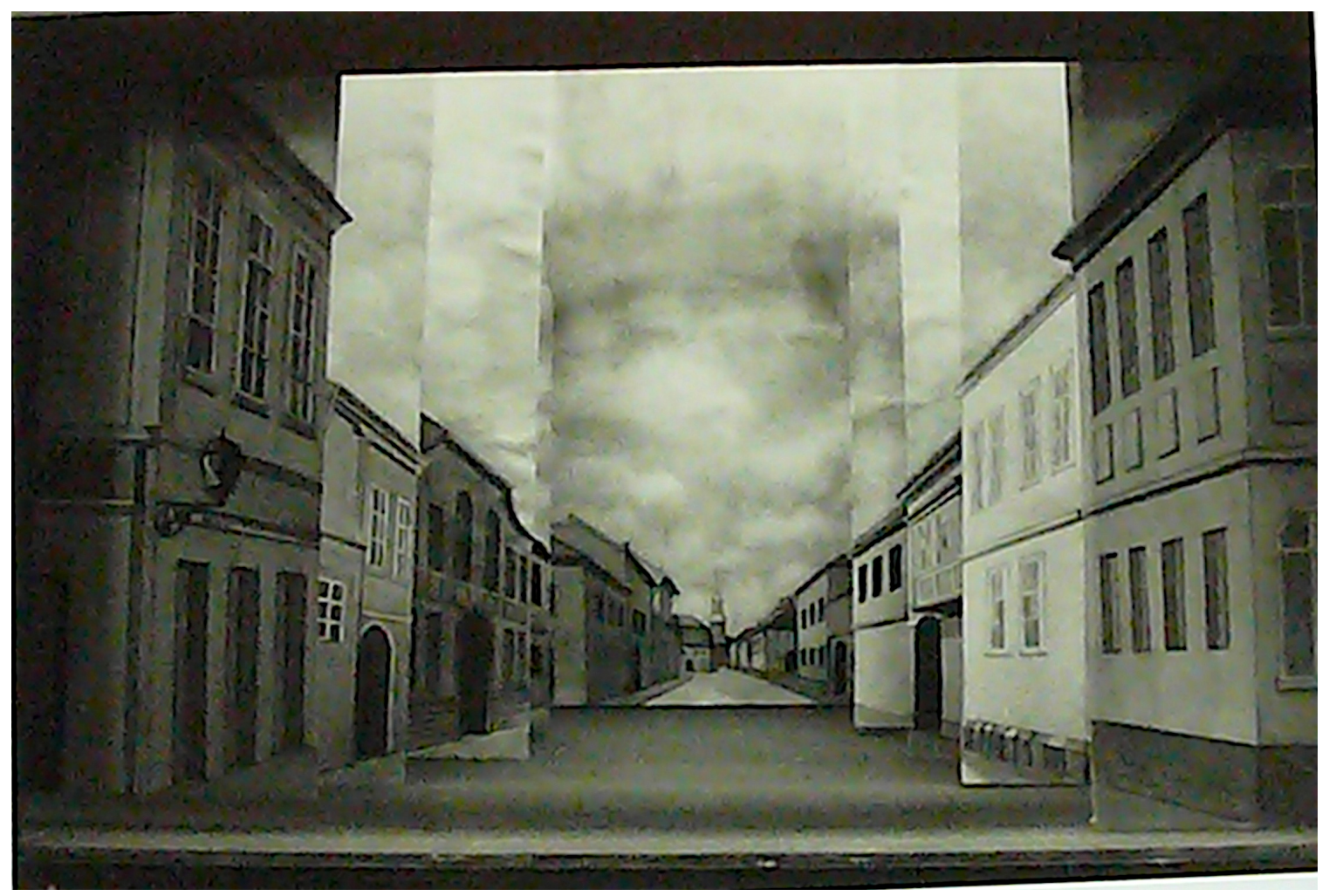

Fig. 2. A scale model made by an unidentified student in Paul Suominen's class of technical drawing 1987. There is a fake perspective making the street look longer and going uphill. Photographer unknown. 
Fig. 3. Spatial compositions made by an unidentified student in Måns Hedström's class 1987. Photographer unknown.
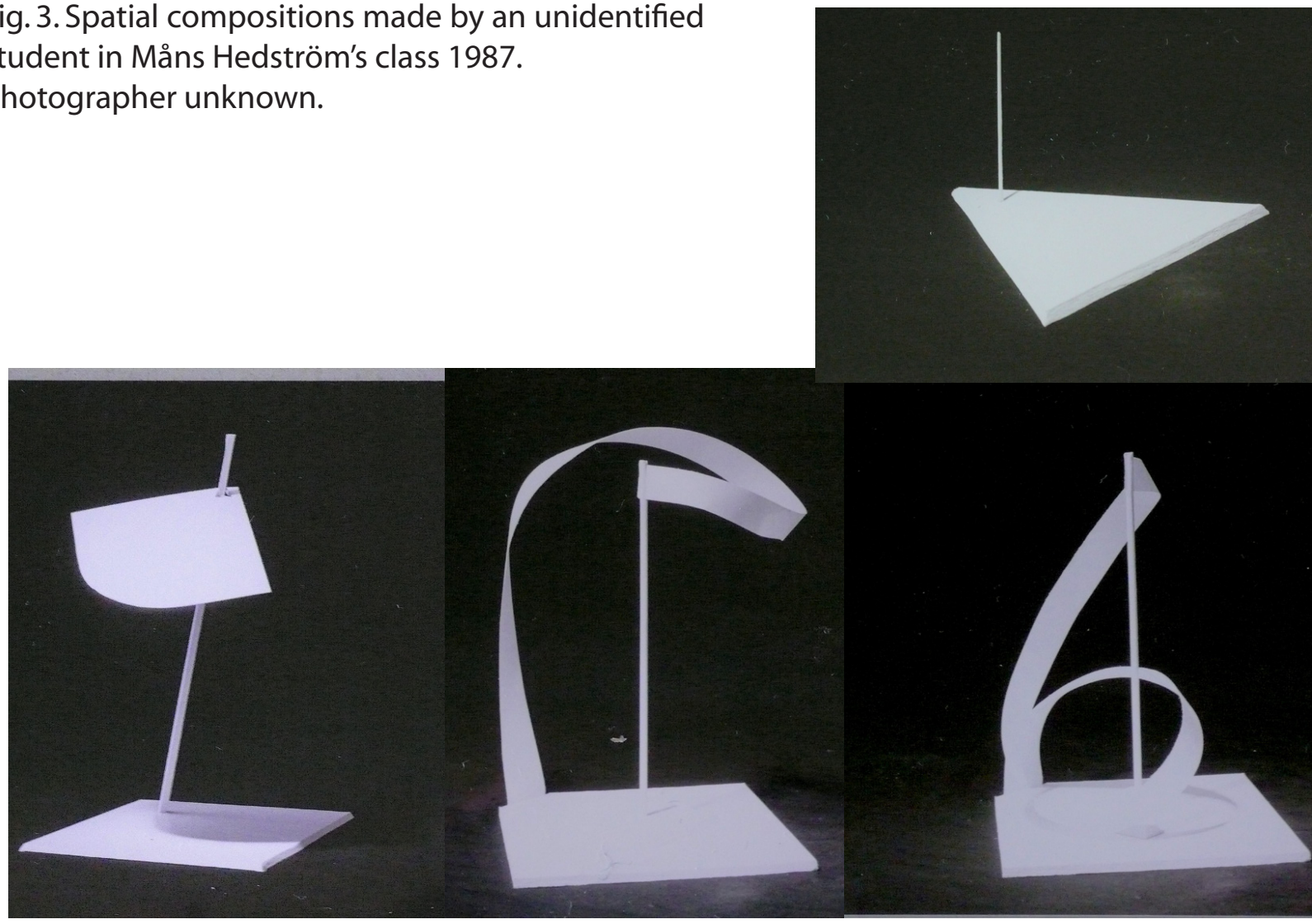

would have taken special interest in Oskar Schlemmer's theorizing on the dynamics of stage space, ${ }^{29}$ but some parallels might be seen in his assignments and lectures examining the basic laws of visual and spatial compositions. Yet, Hedström rather stressed that scenic forms should follow the function: there should be nothing extra on stage, which would not be necessary for acting or interpreting the play. A design by Hedström could be just an idea of arranging or using the stage space in a non-conventional way. This changed the focus of scenography from visual items to the playful potentials of a performative event and created a conceptual level to design. It differed radically from the earlier illustrative and realistic conventions represented by Suominen and resonated strongly with the writings of Bertolt Brecht and Peter Brook that were popular in the 1960s and 1970s.

In his theatre practice, Hedström was very strict that the minimalistic aesthetic was followed. The directors had to solve the scenes just using the given scenographic options, which they experienced as both stimulating and frustrating. ${ }^{30}$ The conceptual idea, developed by the designer, was like an imperative for the whole performance defining its rules. Nevertheless, Hedström clearly put the actor and his need at the centre - given that he, as designer, ultimately knew the needs and the best ways of using the space. In spite of their differences, Suominen and Hedström seemed to share the trust of a designer's superior vision guiding the production process. While Suominen tried to control the construction of the set through technical and artisan skills, Hedström mastered the whole performance by his superior position as an intellectual designer. In some sense, they were both thinking of the production as a linear process from the author's creative idea to a well-planned, executed work. This attitude would be challenged during the next decades.

\section{UPS AND DOWNS IN THE RELATIONSHIP WITH THE THEATRE ACADEMY}

Even though the vocational tuition of scenography was meagre in the 1970s, the students could learn a lot by working at the training theatre Tikapuuteat- 
teri, ${ }^{31}$ which was the pedagogical core of the Theatre Academy, and a visible part of the avant-garde cultural life in Helsinki at that time. ${ }^{32}$ The performances were regularly reviewed in newspapers and visited by theatre makers from all over Finland. ${ }^{33}$ Tikapuuteatteri was run like any professional theatre, but according to the political ideals of the era, students democratically administered it. ${ }^{34}$ The borderline between teachers and students was thin and permeable anyway, since the former were not much older than the latter. There had been a generational shift at the Theatre Academy in $1968,{ }^{35}$ which signified a radical modernist renewal of the artistic guidelines of theatre making. The collaboration with scenography students was systematically developed at least since 1975. They participated in Tikapuuteatteri as full members and learned to get to know the directors and dramaturges of their own generation, who came to reign in Finnish theatre for the following decades. ${ }^{36}$

Dramaturgy was the most important joint study subject between scenographers and the Theatre Academy in the 1970s. It penetrated all disciplines of text-based theatre making and created a common ground for collaboration. By 1974, the teachers of dramaturgy and direction had developed an analytical reading method called Lukutapa ${ }^{37}$, which was a translation from the German word Lesart. According to Timo Kallinen, who has researched the history of the Theatre Academy, it was a domestic version of the early ideas of Stanislavski combined with Brecht, influenced by Aristotle's Poetics, and the rest was self-made. ${ }^{38}$ It aimed, simply put, at a profound understanding of a play's events by closely reading the contents and analysing its deep-structures. The method was taught in the Basic Seminar attended by all students: directors, dramaturges and, in part, actors. Scenographers participated there between 1977-82 and Eeva Ijäs was an assistant teacher there. ${ }^{39}$ She considered dramaturgy as the third corner-stone of the scenography curriculum along with the classes of Suominen and Hedström: "I believe that the form of the stage is connected to the structure of the play. Think for instance about Shakespeare and the Globe." ${ }^{40}$

The scenographic application of the reading method was a so-called sheet, a table of the play-contents drawn scene by scene on a large paper. All hints concerning the setting, atmosphere, props, lights and costumes that could be found in the playtext were written down and usually highlighted by colours and small symbols. The sheet served as a basic tool for design, showing the structure of the play's visual narrative. ${ }^{41}$ It was complemented by fundamental research on the plays historical, social and cultural context. ${ }^{42}$

According to Kallinen, another parallel method was suggested at the Theatre Academy, called Työtapa, "work method". It consisted of practical guidelines for creating the characters and putting the outcomes of the reading method on stage, but it was never developed further. Kallinen considers its neglect as a plausible reason for a narrow comprehension and misunderstanding of Lukutapa. ${ }^{43}$ It became a too theoretical tool, which forgot the actors' needs and the creative potentials of stage rehearsals, and was abandoned by the end of the 1970s. The most important uniting link between the trainings of scenography and direction was thereby lost.

Things changed drastically at the Theatre Academy when the director, Jouko Turkka, was elected rector in 1982 . He put the actor in the centre and used very physical training methods resembling Antonin Artaud and Jerzy Grotowski. Turkka was known as an autocratic director, who used to push actors to their limits. He did not want to collaborate with designers ${ }^{44}$ but created brilliant scenographies of ready-made objects by himself. He only needed a heap of junk in the corner of the stage and the set found its shape through rehearsals operating at the edge of chaos, which according to Janne Tapper was a source of creativity for Turkka. ${ }^{45}$ Nothing would have been more alien to the disciplined linearity of Suominen's production schema or the conceptualizing approach of Hedström.

Tapper has presented an interesting analysis of Turkka's pedagogy as a performance of the cultural logic of new capitalism celebrating free competition and systemic, evolutionary processes. ${ }^{46}$ According to him, there was a shift of legitimation from the great narratives to efficiency and performative potency, which changed the aesthetics, experiences and means. ${ }^{47}$ The move was grotesquely embodied by simulating the new liberalistic conditions 
of working life e.g. by continuously ranking the acting students, emphasizing their measurable results in sports, and turning the educational praxis into a media spectacle. ${ }^{48}$ Respectively, I suggest that Suominen and Hedström were committed to the earlier operational cultures of social capitalism, which according to Richard Sennett was ruled by fixed organizational structures, bureaucracy, social inclusion of citizens and their respective loyalty to institutions. ${ }^{49}$ This, of course, had nothing to do with political views: Suominen, Hedström and Turkka were all known as radical leftists. It is rather a matter of something that Tapper metaphorically calls "pollination", meaning that cultural ways of thinking and behaving spread like pollen to different areas, including theatre practices. ${ }^{50}$ Parallell to the political move from planned economy to free markets in the 1980s, neo-capitalist values like short-term planning, flexibility and adaptation to constant changes emerged in the operational culture of theatre. Free lance practices were favoured instead of fixed contracts, and the previous tradition of well-organized ensemble-work started to dissolve. The rigidly structured process and professional hierarchy of scenic design began to appear as an emblem of an outdated bureaucracy, retarding and blocking free creative processes.

The collaboration between the scenography education and the Theatre Academy had not been unproblematic previously, but now it became impossible. Scenography students were no longer needed in the training productions and Turkka mixed all acting classes into a free ensemble focusing only on performances, ${ }^{51}$ which made all long-term planning and scheduling of other classes very difficult. Since scenographers were tied to the weekly timetables of UIAH, the joint studies with the Theatre Academy came to an end. Despite his indisputable artistic credits, Turkka left the Theatre Academy in 1985 in mayhem, which prevailed for several years. ${ }^{52}$ An almost total breach between scenography training and the Theatre Academy lasted from 1982 to 1992, with the exception of the education of lighting design, which started at the Theatre Academy in 1986 and was based in Tampere 1988-2007. A whole generation of theatre makers grew up without learning to work and discuss together, which probably showed in the reluctance of many young directors to co-operate with scenographers in the late $1980 \mathrm{~s}$ and 1990s. ${ }^{53}$

Liisa Ikonen, who studied scenography 198691, describes how she did not know her fellow students at the Theatre Academy even by name: "We built scale models without any collaboration with directors and the practical needs of performances were not considered. I think that the sense of community in theatre has later become so important for me, because I then had to make my own art alone, without conversations." ${ }^{54}$ Yet, the scenography students were not completely isolated from theatre making. The employment situation was good and institutional theatres willingly hired even first-year design students paying full salaries. Ikonen, however, comments critically: "When you learn the job straight in the field, you have to adapt the prevailing practices there. At the Training Theatre, you could experiment and develop new working methods with your fellow-students and perhaps influence the field together." 55

\section{SCENOGRAPHY AS AN INDEPENDENT DEPARTMENT}

From the 1980s on, the position of scenography education became more autonomous, also within UIAH, because professional-specific studies and identities came to the foreground. ${ }^{56}$ The late $1970 \mathrm{~s}$ had been characterized by furious political conflicts. The art historian, Pekka Korvenmaa, who specializes in Finnish industrial design, connects the polemic to the requirements put on design studies by industry and business life: they criticized the universalizing idealism of Franck's legacy for neglecting professional skills needed in working life. Extreme new-leftists, who had a firm footing in UIAH, saw there an attack by capitalist commercialism and opposed loudly. ${ }^{57}$ After some agitated years, the university reformation of 1979 favoured more specialized, vocational studies, ${ }^{58}$ and the free movement between disciplines was limited. The intimate ambience and shared identity started to dim also because the number of students and teachers in UIAH increased rapidly. ${ }^{59}$ People from different departments did not meet each other so easily because the prem- 
ises were scattered around several places in the city between 1974-86. ${ }^{60}$ The joint classes lost their significance as a common basis for all students. ${ }^{61}$ From now on, the disciplines started to diverge from each other and the unifying Bauhaus-ideology waned.

A generational shift took place in the teaching staff of scenography at the end of the 1980s, which made these years a transition period. Hedström had fallen severely ill and withdrew from his teaching duties in 1987. Suominen, who clearly had lost his motivation, retired in 1991. Eeva Ijäs (born 1951) was appointed as lecturer in 1988 and has, since then, worked full-time at the department and contributed to its development probably more than anybody else. Her classmate Anu Maja (born 1951), who had made her career in television, was elected as associate professor after Suominen in 1991, and started to develop the teaching of production design in film and TV. This had been practically non-existing until that time, although the curriculum had, in theory, offered designing skills for both theatre and cinema from the very start. Maja was soon appointed as vice-rector of UIAH and several surrogate professors worked in the department during the late 1980s and 1990s, e.g. Ijäs, Ensio Suominen, Kaarina Hieta and Kimmo Turunen.

Ijäs describes the 1990s as an innovative time where the university went through endless reformations: "We were developing new studies all the time; we travelled and had international visitors. We got more money than before - but sometimes it was also cut back and we had to cancel courses. But the money was in our own hands - nobody told us what to do; we were free to make plans." ${ }^{2}$

Previously, Scenography had been a part of the Department of Visual Communication, now, it became an independent department. The university reform of 1994 introduced a two-step degree-programme of $3+2$ years. ${ }^{63} \mathrm{~A}$ clear border between BA- and MA-studies in scenography was never established, but the new master's degree obliged the department to develop advanced and theoretical courses besides vocational studies. ${ }^{64}$ Now, the teachers had to formulate the curriculum more specifically and had to develop a conceptual language for their tacit knowledge. All this laid ground for theoretical research. International activity grew no- ticeable, which does not mean that scenography education had been isolated from the rest of the world before. Students had participated regularly in the Prague Quadrenniales ${ }^{65}$ since $1971,{ }^{66}$ and individual teachers had personal contacts abroad. The Erasmus-exchange programme started in the early 1990s and the department began to offer English study units to foreign exchange students in $1996 .{ }^{67}$ A Euro-MA programme was arranged together with two international partner-universities in the mid1990s; the Helsinki section focused on production design in film and $\mathrm{TV}^{68}$

All material and human resources kept improving throughout the 1990s. Until the mid 1980s scenography had been a tiny major with 20 students and one full time teacher. The premises consisted of two small classrooms and a paint-shop. Ten years later, it was the smallest independent department of UIAH with one professor, one lecturer, two additional fulltime teachers and about 30-40 students. ${ }^{69}$ The volume of the premises doubled at the beginning of the 1990s and a small, low-tech studio-stage was placed at the students' disposal. ${ }^{70}$ Before that, they had worked only with miniature scale models, which could be placed on a table; from now on they could make installations and one-to-one spatial experiments. The material growth culminated in the Centre for Audio-Visual Media, LUME, accomplished in 1999. Provided with large film- and TV-studios, a black-box studio stage, wood and metal workshops, and computer classrooms it offered scenographers multiple facilities, which they could not have dreamt of ten years earlier. The department of Film and TV moved for the first time to the same premises with the rest of UIAH, which propelled collaboration with the cinematic arts.

The development of digitalized visual technologies and virtual spaces awakened a new interest in scenography, which probably explains the generosity of resourcing. It also boosted the artistic identity of scenographers as experts of visual and spatial narratives apart from the theatrical context. The use of digitalized technologies was mostly connected to TV and film in the department. In the theatre they were mostly used and developed by lighting designers like Markku Uimonen, who worked as a lecturer in scenography 1997-99. He invited profes- 
sor Robert Shakespeare from Indiana University on a Fulbright scholarship to develop digital design in 1999-2000. After Uimonen's election as professor to the Theatre Academy in 2000, the development of digital culture occured mainly in the fields of cinema and TV at UIAH. ${ }^{71}$

\section{THE SECOND GENERATION OF SCENOGRAPHY TEACHERS}

In the 1990s, many newly trained scenographers started to teach directly after finishing their studies. Their minor practical experience became an issue of criticism. ${ }^{72}$ However, the teaching posts were not really wanted by older professionals, ${ }^{73}$ even though it was customary to work as a designer alongside the educational tasks. Even if these new teachers were fledglings as designers, they all had fresh memories from being a student. They knew what the curriculum consisted of, and most importantly, what it lacked. Liisa Ikonen (born 1964), who worked as an assistant doing licentiate and doctoral studies 1992-2002, put it very similarly to Ijäs who had studied 20 years earlier: "We tried to bring to the education such issues, which had not been taught to us." 74 Students, who returned immediately to the department, seemed to work like a feedback-loop, circulating, criticising and refining study-contents.

Lacking collaboration with the Theatre Academy, the scenography education turned inwards, focusing on working methods that were not connected to live performances. This may sound odd, since the set is by definition a component of a stage event. It can, however, be conceived as a design of spaces with performative potentials, actualized only in the spectator's mind. The stage itself was taken as an artistic agent; an experience in its own terms, instead of being a background or platform for the performance. This comes close to installation art, which according to Claire Bishop is "a situation into which the viewer physically enters, and insists that you regard this a singular totality". ${ }^{75}$ It also resonates with what Erika Fischer-Lichte calls the performative turn taking place since the 1960s: the generation of a sense of immanent materiality and self-referentiality, where "actions signify only what they accomplish", and the stage constitutes reality instead of representing any contents given by the play-text a priori. ${ }^{76}$ The performative approach allowed the scenographers to think of their work as an autonomous experience, which could generate different responses and interpretations in the spectator and not just to fixed meanings.

Ijäs taught now an extensive course called sim-

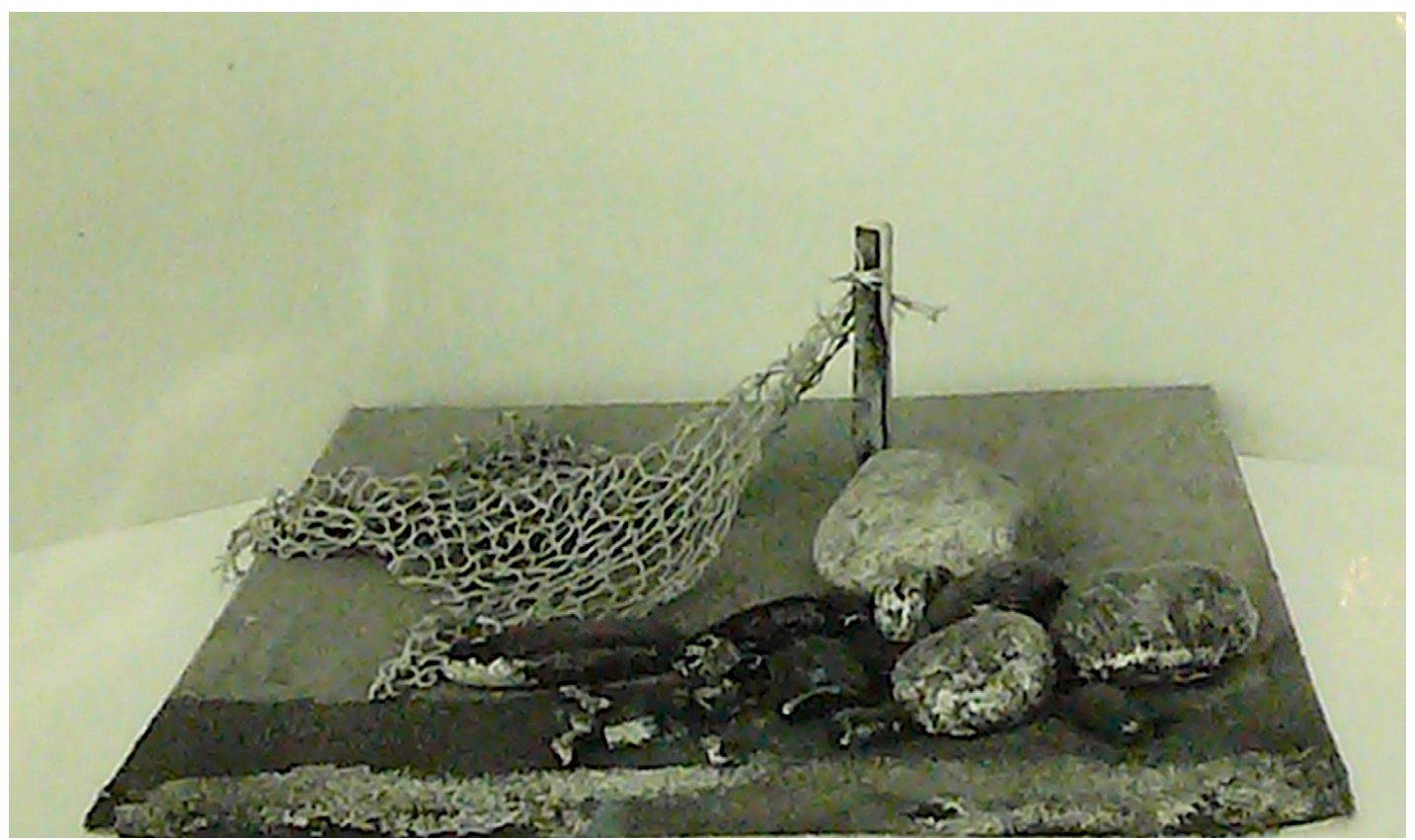

Fig. 4. Spatial composition displaying the themes of Shakespeare's Richard III, made by an unidentified student in Eeva ljäs's class 1987. Photographer unknown. 


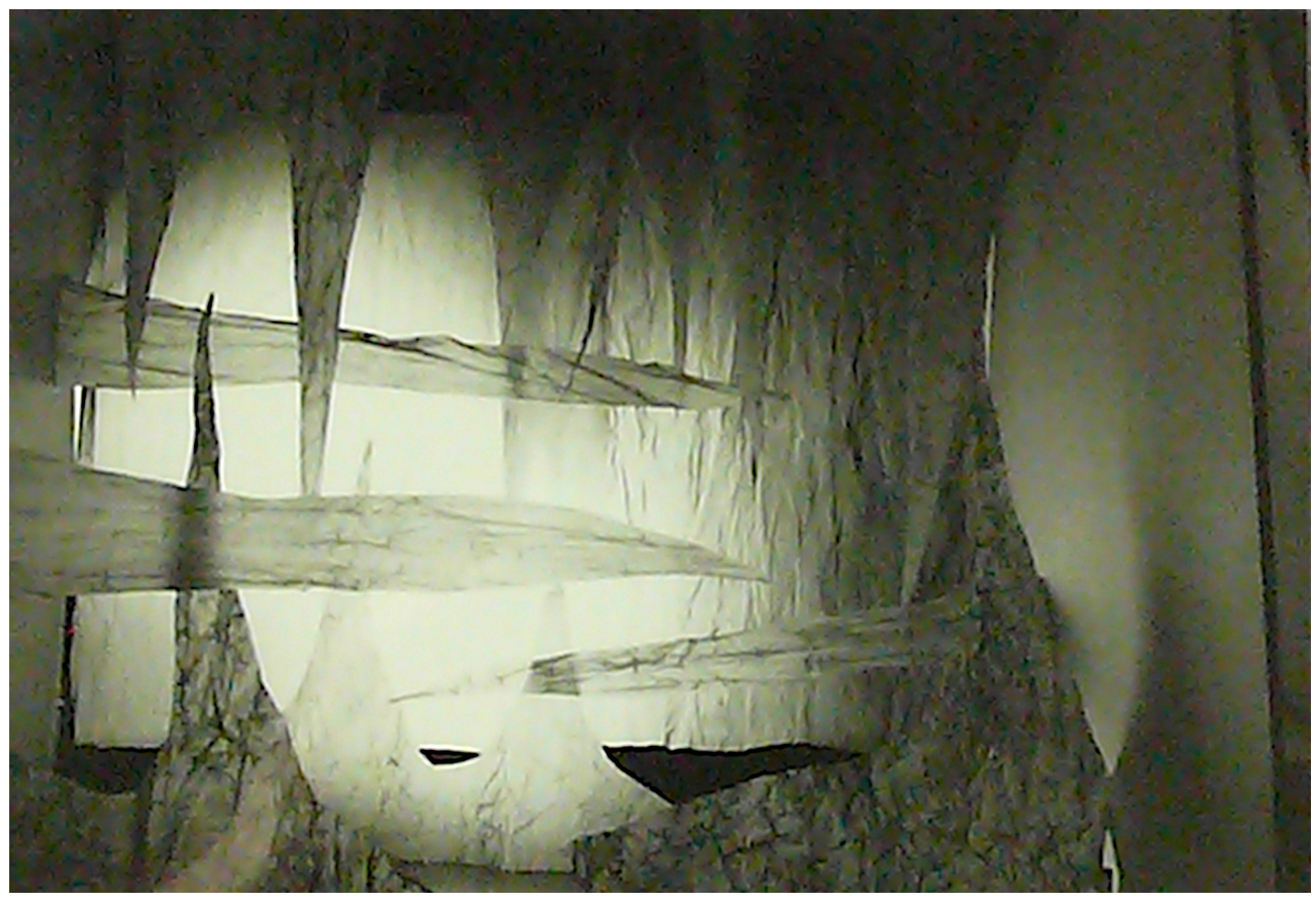

Fig. 5. Spatial composition on the theme: Dream vision of a Finnish landscape made by the second year student Tarja Väätäinen in Eeva ljäs's class 1987. Photographer unknown.

ply 'Scenography I', which became the cornerstone for the education. It was informal teaching that consisted of designs for imaginary productions so- called paper-projects - and small-scale free-form assignments. ${ }^{77}$ For instance, the students were told to construct a space that was a dream vision of the Finnish landscape into a small box using only one material. Otherwise they had free hands. ${ }^{78}$ Ijäs recalled that she tried to avoid illustration and simple realism. The leading idea was to conceptualize one's thoughts so that they could be displayed in visual and spatial form: "For example, I tried to explain to students how power is manifest in Richard III, and how that could be made perceivable in the scenery." 79

Hedström's legacy clearly permeated Ijäs's teaching, but she let go of the purist functionalism and emphasized the students' individual creativity and diversity. Ikonen recalled how Ijäs stressed that everybody was allowed to fail, thus the students felt free to experiment. ${ }^{80}$ Instead of teaching the systematic execution of a well-formulated idea,
Ijäs encouraged the students to give room for their personal creative processes. The permissive attitude also manifested itself in the changing requirements for theses. Until the 1990s, the graduating students were expected to give a complete documentary report of their diploma production, including detailed technical drawings. ${ }^{81}$ Now, they were asked to present their subjective artistic processes. Even the visual format of the thesis was liberated from previous guidelines, causing a flood of creative experimentations with the folders' layout. ${ }^{82}$

When the dust had settled after Turkka's tenure at the Theatre Academy, contacts started slowly to recover during the 1990s. Ijäs created the first joint course, 'Artistic Pre-planning', together with the director Laura Jäntti in 1992. With slight modifications it still makes the skeleton of the studies today. The idea of collective teamwork as a starting point emerged anticipating the popularity of process-based devising methods in the 2000s. The emphasis of scenography studies moved from visual and artisan skills to social and communicative com- 
petence. The exam tests serve as an illuminating example: while they previously consisted of traditional exercises in drawing, painting, sculpting and solving design problems, since 1998, a part of the assignment has been undertaken in teams, and a decisive criterion is the capability to collaborate in a group. ${ }^{83}$

\section{OLD AND NEW PARADIGMS OF SCENIC DESIGN}

During the 1990s, scenographers became more conscious of both their own artistic potential and the significance of teamwork. However, the established practices in the institutional theatre field were based on the old hierarchical organization and the superior position of the director, which frustrated many scenographers with higher ambitions. Liisa Ikonen had taken up doctoral studies with the aim of examining the amalgamation of individual and collective creativity in production processes. ${ }^{84}$ Aspiring for both individual freedom and democratic decision-making, she founded together with the director Tarja Laine an experimental ensemble called Hypnos. They produced eight performances between 1994-2000. In her doctoral thesis, accomplished in 2006, Ikonen applied Heideggerian phenomenology to the outcomes: "The advancing work disengaged scenography from goal-oriented preparation and changed it into an immediate action and participation to an event, creating a work of art in a collective group." ${ }^{85}$ An illustrating example of her teaching was a workshop, where students went to some interesting place, wrote down notes from their inner dialogue with the environment and transformed the text into any kinds of actions or artworks. One student constructed a miniature diorama of a harbour basin; another dealt with her fear of driving: she drove a car through the city centre and documented it on a map. ${ }^{86}$

Along with the growing interest in process-based devising-methods, post-dramatic theatre and participatory art forms, the paradigmatic comprehension of scenography changed in the new millennium. Compared to the earlier guidelines of theatre making, the constitution of an artwork was reversed: it was not anymore an embodiment of previously existing ideas but something new that emerged out of an interactive process that should not be too mastered or calculated beforehand. The focus was now on a receptive encounter between the designer and the unpredictable creative process. Instead of material items or incarnations of conceptual ideas scenography was conceived of as lived experiences, located in human interactions, relations and events. In the context of industrial arts, this was parallel with the idea of Service Design, where the user's action has replaced the material items as the objects of design. The focus of design moves from production to consumption, which can be seen as equivalent to audience-participation in theatre performances. Continuing Tapper's analysis of Turkka's period in the 1980s, these methods can be thought of as a display of more soft and conformable ways of adapting to the post-capitalist conditions. Since we cannot control or plan the processes, we have to find successful ways of operating within the chaos of self-regulating systems without losing human and democratic values.

When scenography was awarded another professorship, specialized on theatre, Tiina Makkonen (1952-2011) was invited to the post in 2001. ${ }^{87}$ She graduated from UIAH in 1979 and due to her long and versatile experience of fieldwork, she was one of the most original and highly valued scenographers in Finland. She also had a clearly articulated philosophy, based on Rudolf Steiner's (1861-1925) anthroposophy. In Makkonen's thinking, scenography was an encounter between an inner, spiritual reality and a bodily experienced materiality. ${ }^{88}$ This resonates with the neo-platonic idealism, which influenced the neo-romantic part of the Bauhaus-tradition discussed before. However, Makkonen's approach was different from functionalism and minimalism. Her scenographies were immersive, multi-modal experiences, which swallowed the spectator into another world. According to her, the stage operates in every performance according its own inner logic, which was a metaphorical parallel to natural laws. ${ }^{89}$

Makkonen was also committed to the analytical reading method of the 1970s and trusted the superior position of the director. She represented the tradition of material pre-planning based on the so-called central metaphor, a leading idea that penetrated all levels of the performance. Thus, her thinking differed radically from that of the students, 
as she pondered in 2005: "In the new scenography you produce fragments. You just throw non-metaphorical pieces together and then look, what kind of 'natural laws' emerge. [...] I always start from the contents - although I sometimes achieve them by working on the form. [...] [I try] to express an abstract idea through concrete material." ${ }^{90}$ Her ideological mismatch with the students was probably one reason for her decision to retreat from the professorship after only a five-year period in 2006. She was also exhausted by the bureaucratic work that increased year by year, and I personally think that she chaired the curriculum in an unfortunate moment and her contribution was largely wasted.

\section{BEING MISPLACED?}

In 2001, scenography education was hastily merged with the Department of Cinema and TV (ELO) and two years later, it was divided into three majors: Stage Design, Production Design for Film and TV, and Costume Design (which was established as a new study subject $\left.{ }^{91}\right)$. With 9-10 fulltime teachers and, altogether, 60-70 BA- and MA-students, the three majors make the present Scenography School. The other component of ELO, the Film School, consists of all cinematic disciplines except design. The organizational structure has proved complex. According to Ijäs, the fusion with ELO put an end as well to the autonomous position of scenography as regard to what was left from the collaboration with other departments in UIAH. ${ }^{92}$ Then again, it is almost impossible to arrange joint courses with Stage Design and the cinematic arts except Production Design, since the Film School focuses only on filmmaking.

Yet, the collaboration with the Theatre Academy has expanded and is now a central part of the study curriculum. Today, stage and costume designers participate regularly in the productions of the Training Theatre and a large number of courses and workshops have been developed: altogether 73 credits of shared studies were offered in 2011-12. ${ }^{93}$ This, however, causes a lot of coordinative work because the two universities have different timetables, study structures and planning practices. ${ }^{94}$ The situation was further complicated when UIAH merged with the Universities of Technology and Economy composing the Aalto University in 2010 and the Theatre Academy was affiliated with the Academies of Fine Art and Music in 2013 to form the Art University.

It seems to me that the curriculum of Stage Design has drifted in a strange organizational position during the early 2000s. It has become a tiny isle of performative arts in the middle of film education. Although professional borderlines are increasingly crossed in contemporary theatre practices, the training of visual design is split into three independent disciplines: set, lighting and costume design. Lighting design, which plays a more and more vital role in contemporary scenography, is taught at the Theatre Academy separately from Stage Design. All attempts to discuss the possibility of restructuring the organization and moving all scenography education to the Theatre Academy have so far been suppressed by UIAH and Aalto University.

Nobody knows what would have happened if the curriculum had been placed at the Theatre Academy in the 1970s. Would the scenographers have survived Turkka's period, or would they, conversely, have been stimulated by the challenge and developed something really innovative? Did the isolation of scenography studies from the Theatre Academy lead to dysfunctional designs? Or, did it urge the scenographers to develop their own art to a new level that made them even more interesting collaboration partners because of their originality matured in the seclusion which only their independent status could grant?

Nobody can tell either what the best strategy for the future would be. My mapping shows how many different factors influence scenography education. The university policies, organizational and administrative structures create circumstances for everyday learning and teaching practices. The students mostly identify the study contents with individual teachers, whose ideas are yet always connected to more general cultural and social developments, pedagogical methods and philosophical comprehensions of art and theatre. Perhaps the most influential component of the education is easily forgotten, since it is the less predictable: the incoming students. Thanks to them, the scenography department has not only been a place for transmitting skills and knowledge, 
it has also served as an arena for contesting, re-evaluating and reforming existing ideologies and practices. 


\section{NOTES AND REFERENCES}

1 Heta Reitala, Harha on totta. Näkökulmia suomalaiseen lavastukseen ja pukusuunnitteluun 1900-luvun alusta nykypäivään, Atena, Helsinki 2005, p. 31

2 Outi Lahtinen, "Koulutusta teatteriammatteihin" in Suomen teatteri ja draama, Mikko-Olavi Seppälä, Katri Tanskanen, eds., Like, Helsinki 2010, pp. 339, 343.

3 Report of the activity of the Scenography Department, UIAH, 1996. Report on the Finnish theatre education by the Ministry of Education, 1979, the private archives of Eeva Ijäs, in the author's possession.

4 The Department of Visual Communication consisted of four degree programmes: Graphic Design, Photography, Film and Television Work, and Scenography.

5 Timo Kallinen, Teatterikorkeakoulun synty. Ammattikoulusta akatemiaksi 1971-1991, Like, Helsinki 2004, pp. 55-6.

6 "Lavastajaliitto: Koulutus yhteen oppilaitokseen" in Helsingin Sanomat, 10 August 1978; a letter from the board of UIAH to the Finnish Parlament, 1 September 1979, the private archives of Eeva Ijäs, in the author's possession.

7 Kallinen, op. cit., p. 56.

8 The placement of scenography education was probably not considered critical in the 1970s since there was a plan to build a shared building for UIAH, the Theatre Academy and the Finnish Film Archive in Pasila but this never happened. The so-called Pasila project was set in motion in 1972 and buried in 1984. Kallinen, op. cit., pp. 54-5.

9 Ilkka Huovio, Invitation from Future. Treatise on the Roots of the School of Arts and Crafts and its Development into a University Level School, Tampere University, Tampere1998, pp. 304-5.

10 Susan Vihma, "Peruskurssi" in Ateneum Maskerad. Taideteollisuuden muotoja murroksia, Yrjö Sotamaa \& al., eds., UIAH, Helsinki 1999, p. 355.

11 Harri Kalha, "Sankarien sukupolvi" in Ateneum Maskerad, op. cit., p. 160; Liisa Räsänen, "Taiteellinen johtaja Kaj Franck" in Ateneum Maskerad, op. cit., pp. 178-9; Vihma, op. cit., p. 355.

12 Kaj Franck, Muotoilijan tunnustuksia,Valtion painatuskeskus, Helsinki, 1989; Räsänen, ibid.; Huovio, op. cit., pp. 259-60.

13 Harri Kalha, Ralf Forström Scenografi 1963-1998, Otava, Helsinki 1999, pp. 10, 18; Reija Hirvikoski, "Vastatuulessa venekin kulkee kovempaa” in Måns Hedström. Te- atterin visuaalinen suunnittelija, Anneli Ollikainen, ed., Theatre Museum, Helsinki 2007, p. 161.

14 Kalha, ibid.; Ollikainen, ibid.

15 Ilkka Huovio, "Veistokoulusta korkeakouluksi" in Ateneum Maskerad, op. cit., pp. 308-39; Eeva Ijäs, interviews with the author, 15 and 24 September 2014.

16 Ijäs, ibid.; Maija Louhio, interview with the author, 14 January 2015.

17 Eeva Ijäs, Pekka Ojamaa, Juhani Pirskanen, Lauri Pitkänen, Solveig Storskubb, Pentti Valkeasuo, Students' working diaries 1968-73, the private archives of Eeva Ijäs, in the author's possession.

18 Ijäs, op. cit.; Louhio, op. cit.; Liisa Ikonen, interview with the author, 12 September 2014.

19 Ijäs, ibid.

20 Paul Suominen, videorecorded interview with Eeva Ijäs, Raimo Tamminen, Seppo Nurmimaa at the Aleksanterinteatteri, 18 November 2008, in the author's possession.

21 Ijäs, op. cit.; my own recollections.

22 Study material and personal notes from Suominen's classes; Ijäs, op. cit.; my own recollections.

23 Suominen, op. cit.

24 Production reports by Oskari Torvinen, Kari Junnikkala, Riina Ahonen, Tarja Jaatinen, Kari Laakkonen, Eeva Ijäs, Tero Kiiskinen, production reports 1974-78, the private archives of Eeva Ijäs, in the author's possession.

25 Ijäs, op. cit.

26 Hirvikoski, op. cit., p. 161.

27 Ijäs, op. cit.; Ikonen, op. cit.; my own recollections.

28 Ikonen, ibid.

29 Oskar Schlemmer, "Man and Art Figure" in The Theater of the Bauhaus, Walter Gropius, A. S. Wensinger, eds., Wesleyan University Press, Middletown, Connecticut 1961, pp. 17-37.

30 Pekka Milonoff, “Älkää unohtako leikkiä” in Ollikainen, op. cit., pp. 89-93; Laura Jäntti, "Haastaja ja kannustaja” in Ollikainen, op. cit. p. 108.

31 Tikapuuteatteri means 'ladder theatre'.

32 Kallinen, op. cit., pp. 31-4. Tikapuuteatteri was operative $1967-79$.

33 Ijäs, op. cit.

34 Kallinen, op. cit., pp. 33-4.

35 Kallinen, op. cit., p. 17; Lahtinen, op. cit., p. 344.

36 Ijäs, op. cit.

37 Kallinen, op. cit., pp. 28-9.

38 Ibid, pp. 23, 29. 
39 Ibid, p. 25; Ijäs, op. cit.

40 Ijäs, op. cit.

41 My own recollections.

42 Ijäs, op. cit.

43 Kallinen, op. cit., p. 29.

44 Katariina Kirjavainen, interview with Jouko Turkka as the assignment of the course "The identity of the scenographer", typed from the recording, 1999, the private archives of Eeva Ijäs, in the author's possession.

45 Janne Tapper, "Työ, työntekijyys ja yhteiskunta Jouko Turkan teatterikoulutuksessa” in Nykynäyttelijän taide. Horjutuksia ja siirtymiä, Marja Silde, ed., TeaK, Maahenki, Helsinki 2011, pp. 125-41, 135-7.

46 Janne Tapper, Jouko Turkan Teatterikorkeakoulun kauden yhteiskunnallinen kontekstuaalisuus vuosina 1982-1985, Helsinki University, Helsinki, 2012, p. 2.

47 Ibid, p. 31.

48 See also: Seppo Kumpulainen, Hikeä ja harmoniaa. Liikunnan ja fyysisen ilmaisun opetus Suomen Teatterikoulun ja Teatterikorkeakoulun näyttelijänkoulutuksessa vuosina 1943-2005, Theatre Academy, Helsinki 2011.

49 Richard Sennett, The Culture of the New Capitalism, Yale University Press, New Haven and London 2006.

50 Janne Tapper, "Jon MacKenzien nykyesityksen teorian tulkinnasta: käsitteet pölytys, immanenssi ja hyve" in Esitystutkimus, Annette Arlander \& al., eds., Partuuna, Helsinki 2015, pp. 169-203.

51 Kallinen, op. cit., p. 82; Kumpulainen, op. cit., pp. 10429.

52 Kumpulainen, ibid., pp. 130-1.

53 e.g. Katariina Kirjavainen, interviews with Juha Hurme and Kristian Smeds as the assignment of the course "The identity of the scenographer", typed from the recording, 1999, the private archives of Eeva Ijäs, in the author's possession. Karin Pennanen, LOPPUtyö, MA-thesis in scenography, UIAH, Helsinki 2005.

54 Ikonen, op. cit.

55 Ikonen, op. cit.

56 Huovio, "Veistokoulusta korkeakouluksi", op. cit., 1999.

57 Pekka Korvenmaa, "Tietoisuuden tasot" in Ateneum Maskerad, op. cit., pp.172-200.

58 Ibid., p. 198; Huovio, "Veistokoulusta korkeakouluksi", op. cit., p. 330.

59 Auli Suortti-Vuorio, "Atskilaiset, taikkilaiset,...keitä?" in Ateneum Maskerad, op. cit., pp. 376-80, https://kotaplus.csc.fi/online/Haku.do.
60 The main premises were in Ateneum until 1983, while some departments were based in different places. At the beginning of the 1970s, scenography was located in Annankatu, and 1974-86 in Kuortaneenkatu, Vallila. In 1986 the whole university except Film and TV moved to the old building of Arabia factories.

61 My own recollection and discussions with my fellow students.

62 Ijäs, op. cit.

63 Ibid., p. 13.

64 Eeva Ijäs, e-mail to the author, 14 April 2015.

65 An international exhibition arranged by OISTAT (the International Organisation of Scenographers, Theatre Architects and Technicians) in Prague in every four years.

66 Ijäs, interviews with the author, op. cit.

67 Self-evaluation report of the scenography department, 1998, p. 2, the private archives of Eeva Ijäs, in the author's possession.

68 Ijäs, interviews with the author, op. cit.

69 Report of the activity of the Scenography Department, UIAH, 1996, the private archives of Eeva Ijäs, in the author's possession.

70 Ijäs, interviews with the author, op. cit.; Ikonen, op. cit.

71 Ijäs, interviews with the author, op. cit.

72 Ikonen, op. cit.; Hirvikoski, op. cit., p. 166.

73 Ijäs, interviews with the author, op. cit.

74 Ikonen, op. cit.

75 Claire Bishop, Installation Art. A Critical History, Tate Publishing, London 2005, p. 6.

76 Erika Fischer-Lichte, The Transformative Power of Performance, Routledge, London and New York, 2008, pp. 20-2.

77 Ijäs, interviews with the author, op. cit.

78 Ikonen, op. cit.

79 Ijäs, interviews with the author, op. cit.

80 Ikonen, op. cit.

81 Requirements for thesis, 1970s, the private archives of Eeva Ijäs, in the author's possession.

82 Master theses of scenography students 1990-2000; Ikonen, op. cit.

83 Self-evaluation report of the scenography department, op. cit., p. 5

84 Liisa Ikonen, Dialogista skenografiaa. Vaihtoehtoisen työprosessin fenomenologista tulkintaa, UIAH, Helsinki, 2006; Liisa Ikonen, Mistä kuvat tulevat? Licentiate Thesis, UIAH, Helsinki 1998. 
85 Ikonen, Dialogista skenografiaa, op. cit., p. 415.

86 Ikonen, interview with the author, op. cit.

87 Katriina Ilmaranta was elected as professor after Anu Maja in 2000. She concentrated on production design in film and television. At first Pekka Ojamaa was elected as the professor of stage design but he left the chair after a couple of months.

88 Tiina Makkonen, "Lavastajan työ ja tila, 30 vuotta totuuden etsimistä", handbill of the exhibition at the Theatre Museum, 2009; archived notes and educational materials, the private archives of Eeva Ijäs, in the author's possession.

89 Tiina Makkonen, interview with the author, 15 June 2005.

90 Ibid.

91 A pilot MA-programme in Costume Design had been arranged 2000-02, and a permanent degree programme with BA and MA degree was established in 2003.

92 Ijäs, interviews with the author, op. cit.

93 Elisa Joro, Taideyliopistojen toiminta-alusta, Theatre Academy / AaltoARTS, Helsinki 2012, pp. 60-1.

94 Ijäs, interviews with the author, op. cit.; my own recollections. 
